\title{
The Effects of Variety-seeking Buying Tendency and Price Sensitivity on Utilitarian and Hedonic Value in Apparel Shopping Satisfaction
}

\author{
Neda Irani (Corresponding author) \\ Department of Business Management, Science and Research Branch \\ Islamic Azad University, Tehran, Iran \\ Ashrafee-e-Esfahani Highway, Hesarak Road, Tehran 1477893855, Iran \\ Tel: 98-21-4486-9667 E-mail: neda_irani@yahoo.com \\ Kambiz Heidarzadeh Hanzaee \\ Department of Business Management, Science and Research Branch \\ Islamic Azad University, Tehran, Iran \\ Ashrafee-e-Esfahani Highway, Hesarak Road, Tehran 1477893855, Iran \\ Tel: 98-21-4486-9667Ｅ-mail: heidarzadeh@srbiau.ac.ir
}

Received: April 12, $2011 \quad$ Accepted: May 20, $2011 \quad$ doi:10.5539/ijms.v3n3p89

\begin{abstract}
This study investigates the effects of Iranian consumers' variety-seeking buying tendency and price sensitivity on utilitarian and hedonic value as influencing factors on shopping experience for Manto and Shirt shoppers in the Iranian market. The main constructs were identified from the literature and then tested relationships between them. A questionnaire developed and successfully administered to a national sample of 1466 women and men in four big cities of Iran through face-to-face interviews. Results are analyzed by Structural Equation Modeling (SEM) and parameters were estimated using maximum likelihood method. Based on this study variety-seeking buying tendency was critical factor of shopping values for Manto and Shirt shoppers. On the contrary, there was a negative relationship between price sensitivity and hedonic value. However, there were no positive relationship between price sensitivity and utilitarian value. Moreover, the result of this study revealed that utilitarian and hedonic value positively influenced shopping satisfaction.
\end{abstract}

Keywords: Variety-seeking buying, Price sensitivity, Utilitarian value, Hedonic value, Shopping satisfaction

\section{Introduction}

Marketers and retailers often seek to learn why people go shopping. Researchers have recently shown that the shopping experience provides consumers with a combination of utilitarian and hedonic shopping value (Holbrook \& Hirschman, 1982; Babin et al., 1994; Babin \& Darden, 1995; Babin et al., 2005; Jones et al., 2006; Cottet et al., 2006; Seo \& Lee, 2008; Carpenter, 2008; Lee et al., 2009). Utilitarian value is task-oriented and cognitive in nature, whereas hedonic value is tied to the emotional aspects of the shopping experience (Holbrook \& Hirschman, 1982; Babin et al., 1994). In general, consumers perceive utilitarian value by acquiring the product that necessitated the shopping trip while simultaneously perceiving hedonic value associated with the enjoyment of the shopping experience itself (Carpenter, 2008).

Since the establishment of the Personal Shopping Value scale approximately a decade ago (Babin et al., 1994), research has focused almost exclusively on antecedents to both hedonic and utilitarian shopping value (Babin et al., 1994; Babin \& Darden, 1995; Griffin et al., 2000; Babin \& Attaway, 2000; Babin \& Babin, 2001; Seo \& Lee, 2008; Babin et al., 2005; Scarpi, 2005; Jones et al., 2006; Carpenter, 2008). Interestingly, previous studies have examined the role of shopping values in determining post-shopping responses such as satisfaction (Babin et al., 1994; Babin et al., 2005; Jones et al., 2006; Cottet et al., 2006), loyalty (Jones et al., 2006; Carpenter, 2008), word of mouth and share of purchases (Jones et al., 2006; Carpenter, 2008), customer share (Babin \& Attaway, 2000), repatronage intentions (Seo \& Lee, 2008; Scarpi, 2005; Jones et al., 2006). 
To date, few researchers have examined the influence of consumers' buying tendencies and the mediating role of utilitarian and hedonic shopping values in shopping experience satisfaction (Chang, 2002, Lee et al., 2009). However, none of these studies have as their central focus the complex interrelationship between shopping value, consumers' buying tendencies and shopping experience satisfaction, even though such relationships would seem to be particularly important given the tremendous amount of resources and expenses that marketers and domestic and foreign investors are devoting to create satisfied and loyal customers. This led the authors to investigate proposition for this study: How variety-seeking buying tendency and price sensitivity effect on utilitarian and hedonic value as influencing factors on shopping experience satisfaction for Manto and Shirt shoppers in the Iranian market?

\subsection{Iran's High Market Potential}

With GDP growth in the 5.8\% range (CIA Fact Book, 2008), the second largest economy in the region, the second largest country in Organization of the Petroleum Exporting Countries (OPEC) oil, the second largest reserves of gas, an estimated population of 71.4 million, economic reformist momentum in the country (UNICEF, 2008), and its young population, Iran is an attractive market for many foreign companies. In the early 2000 s the Iranian government liberalized investment regulations; hence, foreign investors have concentrated their activity in the oil and gas industry, vehicle manufacture, copper mining, petrochemicals, foods, and pharmaceuticals (Library of Congress, Federal Research Division, 2008). The most active foreign investors are German, Norwegian, British, French, Japanese, Russian, South Korean, Swedish, and Swiss companies. Currently, more than 25 automakers in Iran are producing light and heavy vehicles.

These automakers are in joint venture with popular international automakers such as Peugeot (France), Citroen (France), Volkswagen (Germany), Nissan (Japan), Toyota (Japan), Kia Motors (South Korea), Proton (Malaysia), Chery (China) and many other established producers of light and heavy vehicles. Nestle' of Switzerland, LG Electronics Inc., Coca-Cola and Pepsi-Cola of the United States and several other foreign companies also have joint ventures with Iranian companies (Research \& Markets, 2007).

Several European firms are already looking at investing in Iran's clothing and textile industry. Iran is among the world's top 20 textile investment opportunities, and industry experts are convinced there is still a wealth of untapped potential in Iran's textile and clothing industry just waiting to be discovered by overseas investors (Soltani, 2002). One such investment is Benetton Group with seven shopping stores, four in Tehran, two in Mashhad and one in Yazd (Heidarzadeh \& Aghasibeig, 2008). Iran has undergone significant change for the last thirty years after Iran's Islamic revolution. Due to these changes, consumption patterns, investment and other components of domestic demand are all strongly growing. This has created: (1) more disposable income; (2) the emergence of younger consumers; (3) accelerated urbanization; and (4) quality improvement. Enhanced domestic spending power is the basis for the changes in the growth of the economy. Iranian consumers' tastes have become fashionable and stylish in short years and expectations of improved quality and diversity of choice and style have increased. This change in consumption pattern is very visible in Iran's cloth industry. Since Iran is such a young and attractive potential clothing market, there is no empirical study of shopping behavior and shopping value of Iranian consumers; this led the authors to investigate the consumer shopping value phenomenon and contribute to the developing stream of literature and it is necessary to study more diverse dimensions of shopping value perceived by Iranian consumers.

\section{Theoretical Background}

\subsection{Shopping values: Utilitarian and hedonic values}

Value is one of the most powerful forces in the marketplace to understand consumer behavior (Zeithaml, 1988; Dodds et al., 1991; Holbrook, 1996). Value originates from the confrontation between what the customer receives (quality, benefits, worth, utilities), and what he or she gives up to acquire the benefits (price, sacrifices) (Zeithaml, 1988), and thus is defined as a consumer's overall judgment of benefits and sacrifices (Overby \& Lee, 2006). Value plays an important role in predicting customers' choice and future repurchase intentions (Zeithaml, 1988; Dodds et al., 1991; Holbrook, 1996). Thus, value judgment creates consumer preference and this consumer preference increases behavioral intention to participate in various shopping processes (Cronin et al., 2000; Overby \& Lee, 2006).

\subsection{Utilitarian Value}

Holbrook and Hirschman (1982) have stated that in traditional information processing buying model the buyer is a rational decision maker wanting to maximize utility by focusing on tangible benefits of the product. According 
to this model, purchasing has been viewed as a problem solving activity in which consumer moves through a series of logical steps.

Hirschman (1984) asserted that all shopping experiences involve the stimulation of thoughts and/or senses and that they accordingly may be viewed as a process that provides the individual with cognitive (utilitarian) and affective (hedonic) benefits. More specifically, tangible attributes of goods and services provide input to cognitive process and is closely related to assessments of utilitarian value. Thus, a consumer receives utilitarian shopping value when he or she obtains the needed product, and this value increases as the consumer obtains the product more effortlessly (Babin et al., 1994). Early studies on shopping value mostly focus on the utilitarian aspect of shopping (Bloch \& Bruce, 1984). Utilitarian consumer behavior is explained through task-related and rational behavior (Batra \& Ahtola, 1990; Kempf, 1999). Perceived utilitarian shopping value is determined by how much of the consumption need that prompts the shopping experience is met (Seo \& Lee, 2008). This means that the consumer purchases goods in a deliberant and efficient manner (Hirschman \& Holbrook, 1982; Engel et al., 1993). Therefore, utilitarian purchasing behavior is more logical, rational, related to transactions (Sherry, 1990; Batra \& Ahtola, 1990), and associated with more information gathering compared to hedonic purchasing behavior (Bloch \& Richins, 1983). Although this utilitarian approach to consumer shopping values is helpful for analyzing consumer purchases, it offers no framework for measuring product selection and analyzing consumption behavior based on emotional needs (Hirschman \& Holbrook, 1982).

\subsection{Hedonic Value}

Compared to utilitarian value, hedonic shopping value is more subjective and individualistic. Its value is perceived through fun and pleasure as opposed to goal achievement (Hirschman \& Holbrook, 1982). Also, hedonic shopping value reflects the pleasure and emotional worth of shopping (Bellenger et al., 1976). Recently, as the needs of consumers have become more diverse, many studies have begun to focus on hedonic shopping value. In the past, however, there was a considerable lack of papers examining hedonic shopping value compared to utilitarian shopping value (Sherry, 1990). Previous studies have identified and included fun, pleasure, recreation, freedom, fantasy, increased arousal, heightened involvement, new information, escape from reality, and others as hedonic shopping value (Darden \& Reynolds, 1971; Tauber, 1972; Hirschman \& Holbrook, 1982; Babin et al., 1994). Therefore, hedonic shopping value refers to the level of perception where shopping is considered emotionally useful through various positive feelings and worthwhile. Thus, hedonic shopping value can be understood as the emotional benefits the consumer perceives through the shopping experience other than the achievement of the original purchase intent (MacInnis \& Price, 1987). Abstract characteristics of goods and services can contribute to affective elements in shopping and are closely related to hedonic value (Cottet et al., 2006). In a similar context, Babin et al. (1994) defined hedonic shopping value as perceived entertainment and emotional worth provided through shopping activities. As Bloch and Bruce (1984) stated, consumers obtain hedonic value as well as task-related or product acquisition value during the shopping experience.

Hedonic shopping plays both positive and negative roles in consumption regarding consumers' benefit. The negatively extreme form of hedonic shopping is impulse purchase or compulsive shopping. Rook (1987) said impulse shoppers purchase products from a need to purchase rather than a need for a product. Similarly, compulsive shoppers put their values on shopping activity itself rather than a product (Faber \& O'Guinn, 1989). Hedonic shopping is commonly expressed by the recreational aspects of store browsing whether or not a purchase occurs (Bloch \& Richins, 1983; Bloch et al., 1989).

Westbrook and Black (1985) suggested that shopping enjoyment includes the opportunity for social interactions with friends, family or even strangers and the sensory stimulation such as escapisms from routine life, and new information about upcoming trends and fashion.

\subsection{Contrasts between Utilitarian and Hedonic Shopping Values}

Traditional shopping experience measurements have not reflected the total value of the shopping experience as they have failed to recognize and measure many intangible and emotional costs and benefits (Bloch \& Richins, 1983; Hirschman, 1984; Holbrook et al., 1984). Defining shopping value as functional and objective product acquisition is too narrow to reflect the complete shopping experience (Hirschman \& Holbrook, 1982). Although hedonic experiences in shopping are often considered as more important than more the product acquisition, the festive or epicurean side of shopping has been researched less often (Bloch \& Bruce, 1984; Sherry, 1990). Therefore, to measure the complete shopping experience, the hedonic side of shopping must be considered as well as the functional, utilitarian side (Babin et al., 1994).

With or without purchasing, shopping can provide hedonic value some consumers enjoy a product's benefit even without purchasing it (MacInnis \& Price, 1987; Markin et al., 1976). Perceived enjoyment itself is an important 
hedonic benefit through a shopping experience (Bloch et al., 1986). Hedonic value induces increased arousal, heightened involvement, perceived freedom, fantasy fulfillment, and escapism (Bloch \& Richins, 1983; Hirschman, 1983).

On the contrary, utilitarian value is relevant to heuristics, goal fulfillment, and less risk propensity (Batra \& Ahtola, 1990; Engel et al., 1993). Babin et al. (1994) insisted that utilitarian shoppers find value only if the shopping chore is completed successfully and, even better, fastidious manner. Lehtonen (1994) compared two types of shopping value (table 1), hedonic and utilitarian values. According to him, the hedonic shopping activity itself is an end so it does not necessarily include purchases. It is often accompanied by impulse buying. As this kind of shopping is for pleasure, shopping efficiency is not important so there is no clear beginning and end point of shopping. It also emphasizes an experiential aspect of shopping. On the contrary, utilitarian value usually plays a role as a means to an end of achievement of more optimal values and shopping efficiency is emphasized, so shopping is planned and performed out of necessity with rationality in utilitarian shopping.

Although in most shopping situations consumers seek both hedonic and utilitarian values, shopping can be regarded as shopping with a goal or shopping as a goal according to consumer attitude toward shopping (Chang, 2002).

\subsection{Consumers' Buying Tendencies}

Several researchers alluded consumers' buying tendencies such as compulsive behavior, variety-seeking tendency, impulsive buying tendency and price sensitivity as possible significant factors of shopping behavior.

This study considers variety-seeking buying tendency (Bawa, 1990; Steenkamp \& Baumgartner, 1995; Menon \& Kahn, 1995; Kahn, 1995; Van et al., 1996) and price sensitivity (Han et al., 2001; Jin \& Kim, 2003; Goldsmith et al., 2005) as consumers' buying tendencies.

To date, few researchers have examined the influence of consumers' buying tendencies and the mediating role of utilitarian and hedonic shopping values in shopping experience satisfaction. Chang (2002) examined the mediating role of hedonic shopping value in shopping experience satisfaction by investigating the relationships between its assumed antecedents such as involvement, variety-seeking tendency, and physical environment of stores and shopping experience satisfaction. Lee et al. (2009) examined the relationship between consumer characteristics (i.e., compulsive buying behavior, variety-seeking tendency, and price sensitivity) and shopping value (i.e., utilitarian and hedonic) in online auctions. However, none of these studies have as their central focus the complex interrelationship between shopping value, consumers' buying tendencies and shopping experience satisfaction. Overall, this literature describes information on consumers' buying tendency differences in shopping behavior; however, these differences have not been linked to shopping values of the clothing market.

\section{Hypotheses Development}

This study is based on the model (figure 1) linking consumers' buying tendencies including variety-seeking buying tendency and price sensitivity, and shopping values to shopping satisfaction. In the following, all the variables in the model are discussed for their relationships, followed by hypotheses development.

\subsection{The Role of Variety-seeking Buying Tendency on Shopping Values}

Kahn (1995) defined variety-seeking as "the tendency of individuals to seek diversity in their choices of services or goods" (p. 139). He discussed three basic motivations for why consumers seek variety in their purchases. Consumers may seek variety because of an internal need for variety due to satiation of particular attributes or because of a desire for additional stimulation. Consumers may also seek variety because of changes in the external environment. These changes may be directly manipulated by the retailer through changes in the marketing mix such as price or place, or may just be naturally occurring. The third reason why consumers seek variety is as a hedge against uncertainty in future tastes. A varied portfolio of options increases the likelihood that the consumer will be able to choose his or her most preferred option in the future.

Variety-seeking tendency is rooted in need for a change in an attempt to resolve the boredom associated with a brand and a product (Van et al., 1996). Bawa (1990) argued that there are two mutually exclusive types of consumers' variety-seeking: one is a variety-seeking consumer assumed to derive no utility from making habitual (repeat) purchases, and the other, an inertial consumer is similarly assumed to have no utility for variety. As Rogers (1979) argued, “... a tendency to avoid variety may coexist with the tendency to seek variety" (p. 88). Consumers might fluctuate between inertia behavior (brand loyal) and variety-seeking (brand switching) behavior. This reflects the effort of consumers to have Optimum Stimulation Level (OSL) (Steenkamp \& Baumgartner, 1995). Consumers try to increase stimulation in such situations by seeking something different or new relative to their previous choice (McAlister \& Pessemier, 1982; Menon \& Kahn, 1995; Van et al., 1996). 
Variety-seeking has been found to be related to hedonic shopping. According to Holbrook and Hirschman (1982), Variety-seeking was related to nonpurposeful behavior (exploratory purchase behavior) and it should be understood by the view of hedonic consumption because it cannot be accounted for by the traditional perspective of utility driven consumption. This construct has generated considerable research attention in consumers' shopping behavior. Variety-seeking tendency has been identified as an important shopping motivation and an influential factor in shopping channel patronage (Michaelidou et al., 2005). It also has been associated with feeling-based decision making and hedonic shopping motivations (Sharma et al., 2006). Feelings of excitement and gratification can be generated by finding a variety of items (Kahn \& Isen, 1993) and by encountering rare, novel, and innovative items (Roehm \& Roehm, 2005). Chang (2002) studied the relationship between the variety-seeking buying tendency and hedonic shopping value in apparel. He found that there is a positive relationship between variety-seeking tendency and hedonic shopping value. That is, consumers who sought variety and stimulation from shopping were more likely to have hedonic shopping value rather than utilitarian value. Similarly, Lee et al. (2009) found that there is a positive relationship between variety-seeking tendency and utilitarian and hedonic values in online auctions. The positive relationship between variety-seeking tendency and utilitarian value suggests that variety seekers evaluate online auction as providing high utilitarian value. Therefore, greater product diversity helps buyers to reduce time costs and increase shopping efficiency. At the same time, variety seekers evaluated online auctions as providing high hedonic value. This means that variety-seeking tendency is an important consumer characteristic influencing hedonic shopping value. It was verified that variety provides pleasant stimulation and novelty that increases excitement and enjoyment in shopping (Steenkamp \& Baumgartner, 1995; Roehm \& Roehm, 2005; Lee et al., 2009). In sum, variety-seeking likely influences both utilitarian and hedonic value. Based on this,

H1: A variety-seeking buying tendency will directly influence utilitarian value.

H2: A variety-seeking buying tendency will directly influence hedonic value.

\subsection{The Role of Price Sensitivity on Shopping Values}

Marketers and researchers are familiar with the concept of price elasticity, which describes changes in the quantity of demand for a product associated with changes in price of the product. If demand is elastic, changes in price level have a proportionally greater impact on demand. Inelastic demand describes the case where changes in price have little effect on demand. The concept of price elasticity describes the aggregate response of a market segment to price levels. Price sensitivity is an individual difference variable describing how individual consumers react to price levels and changes in price levels. A consumer high in price sensitivity will manifest much less demand as price goes up (or higher demand as price goes down), and consumers low in price sensitivity will not react as strongly to a price change (Goldsmith \&Newell, 1997).

Marketing management pricing strategies and buyers' responses to prices have received a great deal of scholarly attention, but most of this research has focused on the aggregate response of the market, price elasticity, and not on individual consumer response (Gatignon, 1984; Kanetkar et al., 1992). It is important to assess the level of price sensitivity among consumers, especially for innovators, prior to and during the introduction stage of the product life cycle (PLC). It is also important to measure price sensitivity for the later buyers, particularly as the new product moves into the growth and maturity stages of the PLC. Finally, consumers often use price as in indicator of quality, especially where they have little knowledge of the product and where they have few alternative brands to compare (Goldsmith \&Newell, 1997).

Price sensitivity is the extent to which consumers perceive and react to price levels and price changes (Goldsmith et al., 2005) and works as a barometer of how much a consumer will pay in the market. Thus, price has a significant influence on consumers' purchase behavior and consequently on sales and profits of the firm (Han et al., 2001).

Price-sensitive consumers were traditionally viewed as rational and logical problem solvers emphasizing utilitarian shopping value (Tauber, 1972; Schindler, 1989). However, researchers have begun to view them as those who seek hedonic value from bargain hunting. For instance, Jin and Kim (2003) found that hedonic and recreational shoppers exhibited high price sensitivity by hunting bargains and using coupons. Other researchers (Babin et al., 1994; Arnold \& Reynolds, 2003) also noted a positive relationship between bargain perception and hedonic shopping value. Babin et al. (1994) expected that the consumers' bargain perceptions to influence shopping value. They discussed that price discounts create transaction utility or smart shopper feelings, which may increase hedonic value. In addition, price discounts could create utilitarian value by facilitating an efficient end to the product-acquisition task. Consistent with this reasoning, they found that consumer bargain perceptions relate significantly to both hedonic value and utilitarian value. They suggested that if substantiated by future 
studies of price discounts and shopping value, these findings may indicate that the subjective emotional component of price promotions is at least as important as the more tangible component. However, Lee et al. (2009) found that there is a negative relationship between price sensitivity and hedonic shopping value. In addition, there was no relationship between price sensitivity and utilitarian value. This result indicates that consumers who participate in online auctions are not price sensitive. Many shoppers use online auctions to find rare and unusual items, or a quality items with a good deal, rather than to find just low-priced or inexpensive items. Also, auction participants have a feeling of attachment to auction items when bidding duration gets long. Hence, it can be posited that price sensitive consumers obtain higher levels of utilitarian and hedonic value. Thus,

H3: Price sensitivity will directly influence utilitarian value.

H4: Price sensitivity will directly influence hedonic value.

\subsection{The Role of Shopping Values in Shopping Satisfaction}

The generally accepted and most widely applied method for conceptualizing consumer satisfaction is Oliver's Expectancy-Disconfirmation model (1980). The model contends that attitudes about a purchase experience, product or service lead form expectations in the mind of the consumer. After the consumer purchases and/or uses the product or service, they evaluate the purchase experience and the performance of the product or service relative to their initial expectations. The outcome of this evaluation is an attitude- a decision to be satisfied or dissatisfied. If the evaluation and subsequent attitude confirms the consumer's expectations of the purchase experience, product or service, a state of satisfaction occurs. This state of satisfaction leads to a positive attitude toward the purchase experience, product and/or service, and can positively influence future purchase intentions. However, if the evaluation and subsequent attitude disconfirms the consumer's expectations, a state of dissatisfaction occurs; thus, future purchase intentions could be negatively affected. Also, for a specific transaction, by analyzing Holbrook's typology, Oliver (1993) concluded that consumption value may enhance satisfaction.

Babin et al. (1994), by testing the discriminating validity of the scale they suggest, show the impact of the hedonic and utilitarian values on satisfaction. Other researchers stressed the impact of shopping values on satisfaction (Babin et al., 1994; Jones et al., 2006; Cottet et al., 2006; Carpenter, 2008). For instance, Cottet et al. (2006) found that there is a positive relationship between shopping values and satisfaction. In this study, in a food products context, the hedonic value plays a key role in the satisfaction process. It explains satisfaction better than a utilitarian value does. Similarly, Carpenter (2008) examined the relationships between consumer shopping value, satisfaction and loyalty in retailing. In this research utilitarian and hedonic shopping values are found to influence key outcome variables including satisfaction, loyalty, word of mouth communication and share of purchases in the highly competitive discount retail sector. Therefore, the following hypotheses are offered.

H5: Utilitarian value will directly influence shopping satisfaction.

H6: Hedonic value will directly influence shopping satisfaction.

\section{Methods}

This study tested a conceptual model (figure 1) depicting the relationships among consumers' buying tendency including variety-seeking buying tendency and price sensitivity, shopping values, and shopping satisfaction in Iran's clothing industry. The model describes that variety-seeking buying tendency and price sensitivity influence shopping values, which in turn influence shopping satisfaction.

\subsection{Data Collection and Sampling}

To attain the aims of study, based on the product (Manto for female shoppers and Shirt for male shoppers) two different version of one questionnaire was developed and completed by 1540 respondents. The sample for the study was drawn from female and men shoppers in four major cities in Iran; Tehran, Mashhad, Isfahan and Shiraz. Tehran is the capital of Iran located in the center, which has been greatly influenced by different lifestyles; Mashhad is the largest city located in the eastern region, which is largest religious city in Iran with traditional lifestyle; Isfahan and Shiraz in the center of Iran, representing the more historical part of the country. Data were collected from shopping malls located in these four major cities in Iran. The target population for this study consisted of female shoppers who purchased a Manto and male shoppers who purchased a Shirt in their recent shopping trip. Manto is a long dress has gradually evolved into a shoulder-to-ankle smock called a Manto after the French word Manteau (Overcoat). In Iran today, Manto is the norm for everyday public wearing for women like a shirt for men. 
To obtain a sample of Manto and Shirt shoppers, 35 shopping malls in these cities have been selected by cluster random sampling; 20 shopping malls in Tehran and 5 shopping malls in each of three other cities.

Sample size was determined using the Krejcie and Morgan (1970) table and considering the population size of each city. The aim was to collect data from 450 females. and 470 males in Tehran, 142 females and 144 males in Mashhad, 93 females and 96 males in Isfahan and 71 females and 74 males in Shiraz. The data collection resulted in 1466 usable questionnaires from 1540 respondents.

A Marketing research firm with expertise in research methods was contracted to carry out data collection during September 2010 by face-to-face interviews. Trained interviewers administered the survey during a 3-week period.

The average age of respondents was 33 years. A total of $63 \%$ of the respondents were employed and $37 \%$ were unemployed. With regard to education level $32 \%$ had graduated from college or a higher level institution, $21 \%$ had completed junior college, $41 \%$ had completed high school, and $6 \%$ had lower than a high school education.

\subsection{Measures}

The measures consisted of variety-seeking buying tendency, price sensitivity, shopping values (hedonic and utilitarian value), and post-shopping responses (shopping satisfaction). Variety-seeking buying tendency (alpha = .94), from previous studies (Steenkamp \& Baumgartner, 1995; Baumgartner \& Steenkamp, 1996; Chang, 2002; Lee et al., 2009); price sensitivity (alpha $=.94)$, from Goldsmith et al. $(2005)$. Utilitarian value (alpha $=.84$ ) and hedonic value (alpha $=.90)$ as shopping value scales in this study were adapted from Babin et al. (1994). The scale items for shopping satisfaction (alpha $=.86$ ) were adopted from Ganesan (1994), Maxham and Netemeyer (2002), Jones et al. (2006), Chang (2002) and Carpenter (2008). Each item was rated on a 5-point scale anchored by "strongly disagree" (1) and "strongly agree" (5). Table 2 shows the final measurement items organized by construct.

\section{Result}

The proposed model consists of two exogenous variables (variety-seeking, price sensitivity) and three endogenous variables (utilitarian value, hedonic value and shopping satisfaction). Structural Equation Modeling (SEM) with Lisrel 8.80 was used to analyze the data and parameters were estimated using maximum likelihood method. Following Confirmatory Factor Analyses (CFA) and the structural models were tested.

\subsection{Structural Model and Hypotheses Testing}

A structural model was constructed to examine the hypothesized relationships among constructs. Goodness-of-fit statistics, indicating the overall acceptability of the structural model analyzed, were acceptable: $\chi^{2}(622)=$ 4595.02, $p<.000$; RMSEA $=.066$, CFI $=.95$ (table 2 and 3). The result of hypotheses testing can be found in figure 2. Table 2 shows variables and their Measures (Confirmatory Factor Analysis); and table 3 presents standardized coefficients and fit statistics for the structural model. As posited in hypothesis 1 and 2, indicating significant relationship between variety-seeking buying tendency and both utilitarian $(\gamma=.23, \mathrm{t}=5.34, p<.01)$ and hedonic $(\gamma=.41, \mathrm{t}=8.96, p<.01)$ shopping values. However, hypotheses 3 was not supported with no significant relationship between price sensitivity and utilitarian value $(\gamma=.01, \mathrm{t}=.42, p<.05)$. On the contrary, there was a negative relationship between price sensitivity and hedonic value $(\gamma=-.11, \mathrm{t}=-5.43, p<.01)$ supported hypotheses 4 . A direct relationship between utilitarian value and shopping satisfaction $(\beta=.41, \mathrm{t}=$ $15.35, p<.01)$ and hedonic value and shopping satisfaction $(\beta=.24, \mathrm{t}=11.00, p<.01)$ supported hypothesis 5 and 6.

\section{Discussion, Conclusion and Managerial Implications}

The finding of this study presents important insights and implications for Iran clothing industry and domestic and foreign investors. The positive relationship between variety-seeking buying tendency and utilitarian value suggests that variety seekers evaluate Manto or Shirt shopping as providing high utilitarian value. Greater product diversity helps shoppers to reduce time costs and increase shopping efficiency, which supports the finding of Lee et al. (2009). At the same time, variety seekers evaluated Manto or Shirt shopping as providing high hedonic value. This means that variety-seeking tendency is an important consumer buying tendency influencing hedonic shopping value. It was verified that variety provides pleasant, stimulation and novelty that increases excitement and enjoyment in shopping (Steenkamp \& Baumgartner, 1995; Roehm \& Roehm, 2005; Chang, 2002; Lee et al., 2009).

The negative relationship between price sensitivity and hedonic value implies that Manto or Shirt shoppers are not price sensitive. This result supports the finding of Lee et al. (2009). However, there was no relationship 
between price sensitivity and utilitarian value. Although Manto or Shirt shoppers may be sensitive to an initial price at the early stage of Manto or Shirt shopping, an excited and competitive shopping trip may increase a willingness to pay more for a desirable, fashionable or new Manto or Shirt and decrease price sensitivity for a final price.

Both Utilitarian and hedonic value equally influenced shopping satisfaction which supports the findings of Babin et al. (1994), Chang (2002), Eroglu et al. (2005), Jones et al. (2006) and Carpenter (2008). This reveals that shopping satisfaction for Manto or Shirt shoppers is a response to different levels of utilitarian and hedonic value in a shopping trip. In other words, increasing consumers' shopping satisfaction could be manipulated by enhancing consumers' utilitarian and hedonic shopping value. Therefore, the influence of variety-seeking buying tendency and price sensitivity on shopping experience satisfaction may be moderated through manipulating utilitarian and hedonic shopping value.

These results have broader theoretical implications with respect to our understanding of the role of utilitarian and hedonic shopping value in explaining shopping satisfaction. The present study provides not only observed associations among variables related to clothing shopping but also the structural dimensionality including mediating variables of utilitarian and hedonic value in the construct of clothing shopping satisfaction.

This study offers new insights into the nature of consumers' utilitarian and hedonic value and development of the more exciting shopping environment which makes consumers get more involved in their clothing shopping and enjoy more their shopping, and in turn, feel more satisfied with their shopping.

As confirmed in the structural modeling, for apparel (Manto and Shirt) Marketing in the Iranian market, efforts should be indentifying what the causal variables of utilitarian and hedonic value are. Based on the results of the present study, shopping satisfaction can be increased through manipulating consumers' utilitarian and hedonic value. For Manto and Shirt shoppers because consumer buying tendencies such as variety-seeking and price sensitivity were found to affect their utilitarian and hedonic value, meeting their intrinsic needs and wants can be important managerial strategy. Providing variety of new products, provision of better assortment of products, friendly sales personnel, and exciting shopping environments, providing shopping information regularly, and offering a high level of service might make shopping activities more recreational, enjoyable, and functional.

In addition, information on consumers' buying tendencies including variety-seeking buying tendency and price sensitivity, shopping values, and the relationships between them will be useful for domestic and foreign marketers targeting Iranian markets. For Iran's clothing industry, an understanding of Iranian shoppers' behavior, with particular reference to their buying tendencies and shopping values, is crucial. Profiling consumers by identifying their consumer buying tendencies and shopping values provide more meaningful ways to identify and understand various consumer segments and to target each segment with more focused marketing strategies.

\section{Limitations and Future Research}

This study has limitations. First we used the scale set by Babin et al. (1994) to measure value, because it seemed to be best adapted to our study. However, for Iranian apparel we would consider other values based on Iranian culture, values and principles for women and men, therefore, it would be interesting in the future to take other dimensions of value into account and therefore use another scale based on Iranian values. Second, the sample size was determined based on Krejcie and Morgan (1970) table which limit the sample size of research. Future research should attempt to improve on the results of this study, and more representative samples are needed that include broader geographic locations and cross-national comparisons in Iran. Third, a limitation was using only one product category (apparel) and two main products (Manto and Shirt). Therefore, this study could be extended to different product categories (cosmetics, home furnishings, accessories) and other areas of retailing such as grocery shopping and holiday shopping. Forth, the present study includes only two types of consumer buying tendencies; variety-seeking buying tendency and price sensitivity, for future research other possible consumer buying tendencies such as compulsive buying tendency (Hirschman, 1992; Faber \& O'Guinn, 1992; O'Guinn \& Faber, 1989; Rook, 1987) and impulsive buying tendency (Rook, 1987; Bayley \& Nancarrow, 1998; Dittmar et al., 1996; Rook \& Fisher, 1995; Beatty \& Ferrell, 1998; Hausman, 2000) could be tested. Finally, considering the findings of previous research that product involvement can influence shopping behavior (Laurent \& Kapferer, 1985; Kim, 2005; Martin, 1998; Park et al., 2006; Bloch \& Richins, 1983; Zaichkowsky, 1985; Bloch et al., 1989; Bloch et al., 1986; Jones \& Reynolds, 2006; Smith \& Carsky, 1996), future research can incorporate this variable when examining shopping values in apparel shopping satisfaction. 


\section{References}

Arnold, M. J., \& Reynolds, K. (2003). Hedonic shopping motivations. Journal of Retailing, 79(2), 77-95, doi:10.1016/S0022-4359(03)00007-1, http://dx.doi.org/10.1016/S0022-4359(03)00007-1.

Babin, B., \& Attaway, J. (2000). Atmospheric affect as a tool for creating value and gaining share of customer. Journal of Business Research, 49(2), 91-99, doi:10.1016/S0022-4359(03)00007-1, http://dx.doi.org/10.1086/209376.

Babin, B., \& Babin, L. (2001). Seeking something different? A model of schema typicality, consumer affect, purchase intentions and perceived shopping value. Journal of Business Research, 54(2), 89-96, doi:10.1016/S0148-2963(99)00095-8, http://dx.doi.org/10.1016/S0148-2963(99)00095-8.

Babin, B., \& Darden, W. (1995). Consumer self-regulation in a retail environment. Journal of Retailing, 71(1), 47-70, doi:10.1016/0022-4359(95)90012-8, http://dx.doi.org/10.1016/0022-4359(95)90012-8.

Babin, B., Darden, W., \& Griffin, M. (1994). Work and/or fun: measuring hedonic and utilitarian shopping value. Journal of Consumer Research, 20(4), 644-656, doi:10.1086/209376, http://dx.doi.org/10.1086/209376.

Babin, B., Yong-ki, L., Eun-ju, K., \& Griffin, M. (2005). Modeling consumer satisfaction and word-of-mouth: restaurant patronage in Korea. Journal of Services Marketing, 19(3), 133-139.

Batra, R., \& Ahtola, O. (1990). Measuring the hedonic and utilitarian sources of consumer attitudes. Marketing Letters, 2(2), 159-170.

Baumgartner, H., \& Steenkamp, J. E. M. (1996). Exploratory consumer buying behavior: conceptualization and measurement. International Journal of Research in Marketing, 13(2), 121-137, doi:10.1016/0167-8116(95)00037-2, http://dx.doi.org/10.1016/0167-8116(95)00037-2.

Bawa, K. (1990). Modeling inertia and variety-seeking tendencies in brand choice behavior. Marketing Science, 9(3), 263- 278, doi:10.1287/mksc.9.3.263, http://dx.doi.org/10.1287/mksc.9.3.263.

Bayley, G., \& Nancarrow, C. (1998). Impulse purchasing: a qualitative exploration of the phenomenon. Qualitative Marketing Research: An International Journal, 1(2), 99-114.

Beatty, S., \& Ferrell, M. (1998). Impulse buying: modeling its precursors. Journal of Retailing, 74(2), 169-191, doi:10.1016/S0022-4359(99)80092-X, http://dx.doi.org/10.1016/S0022-4359(99)80092-X.

Bellenger, D., Steinberg, E., \& Stanton, W. (1976). The congruence of store image and self image. Journal of Retailing, 52(1), 17-32.

Bloch, P., \& Bruce, G. (1984). Product involvement as leisure behavior. Advances in Consumer Research, 11(1), 197-202.

Bloch, P., \& Richins, M. (1983). Shopping without purchase: an investigation of consumer browsing behavior. Advances in Consumer Research, 10(1), 389-393, doi:10.1086/208946, http://dx.doi.org/10.1086/208946.

Bloch, P., Ridgway, N., \& Sherell, D. (1989). Extending the concept of shopping: an investigation of browsing activity. Journal of the Academy of Marketing Science, 17(1), 13-21, doi:10.1007/BF02726349, http://dx.doi.org/10.1007/BF02726349.

Bloch, P., Sherrell, D., \& Ridgway, N. (1986). Consumer search: an extended framework. Journal of Consumer Research, 13(1), 119-126, doi:10.1086/209052, http://dx.doi.org/10.1086/209052.

Carpenter, J. M. (2008). Consumer shopping value, satisfaction and loyalty in discount retailing. Journal of Retailing \& Consumer Services, 15(5), 358-363, doi:10.1016/j.jretconser.2007.08.003, http://dx.doi.org/10.1016/j.jretconser.2007.08.003.

Central Intelligence Agency (2008). The world fact book, Iran, Central Intelligence Agency. [Online] Available: https://www.cia.gov/library/publications/the-world-factbook/geos/ir.html (accessed 12 September 2010).

Chang, E. (2002). The mediating role of shopping value in apparel shopping satisfaction, Ph.D. dissertation, Oregon State University.

Cottet, P., Lichtlé, M., \& Plichon, V. (2006). The role of value in services: a study in a retail environment. Journal of Consumer Marketing, 23(4/5), 219-227.

Cronin Jr., J., Brady, M., \& Hult, G. (2000). Assessing the effects of quality, value, and customer satisfaction on consumer behavioral intentions in service environments. Journal of Retailing, 76(2), 193-205, doi:10.1016/S0022-4359(00)00028-2, http://dx.doi.org/10.1016/S0022-4359(00)00028-2. 
Darden, W., \& Reynolds, F. (1971). Shopping orientations and product usage rates, Journal of Marketing Research (JMR), 8(4), 505-508, doi:10.2307/3150244, http://dx.doi.org/10.2307/3150244.

Dittmar, H., Beattie, J., \& Friese, S. (1996). Objects, decision considerations and self-image in men's and women's impulse purchases. Acta Psychologica, 93, 187-206, doi:10.1016/0001-6918(96)00019-4, http://dx.doi.org/10.1016/0001-6918(96)00019-4.

Dodds, W., Monroe, K., \& Grewal, D. (1991). Effects of price, brand, and Store information on buyers' product evaluations. Journal of Marketing Research (JMR), 28(3), 307-319, doi:10.2307/3172866, http://dx.doi.org/10.2307/3172866.

Engel, J. F., Blackwell, R. D., \& Miniard, P. W. (1993). Consumer behavior ( $6^{\text {th }}$ ed.), The Dryden Press, Chicago, IL.

Eroglu, S. A., Machleit, K., \& Barr, T. (2005). Perceived retail crowding and shopping satisfaction: the role of shopping values. Journal of Business Research, 58(8), 1146-1153, doi:10.1016/j.jbusres.2004.01.005, http://dx.doi.org/10.1016/j.jbusres.2004.01.005.

Faber, R., \& O'Guinn, T. (1989). Classifying compulsive consumers: advances in the development of a diagnostic tool. Advances in Consumer Research, 16(1), 738-744.

Faber, R., \& O'Guinn, T. (1992). A clinical screener for compulsive buying. Journal of Consumer Research, 19(3), 459-469, doi:10.1086/209315, http://dx.doi.org/10.1086/209315.

Ganesan, S. (1994). Determinants of long-term orientation in buyer-seller relationships. Journal of Marketing, 58(2), 1-19, doi:10.2307/1252265, http://dx.doi.org/10.2307/1252265.

Gatignon, H. (1984). Competition as a moderator of the effect of advertising on sales. Journal of Marketing Research, 21(November), 387-98, doi:10.2307/3151465, http://dx.doi.org/10.2307/3151465.

Goldsmith, R. E., \& Newell, S. J. (1997). Innovativeness and price sensitivity: managerial, theoretical and methodological issues. Journal of Product \& Brand Management, 6(3), 163-174.

Goldsmith, R., Kim, D., Flynn, L., \& Kim, W. (2005). Price sensitivity and innovativeness for fashion among Korean consumers. Journal of Social Psychology, 145(5), 501-508, doi:10.3200/SOCP.145.5.501-508, http://dx.doi.org/10.3200/SOCP.145.5.501-508.

Griffin, M., Babin, B., \& Modianos, D. (2000). Shopping values of Russian consumers: the impact of habituation in a developing economy. Journal of Retailing, 76(1), 33-52, doi:10.1016/S0022-4359(99)00025-1, http://dx.doi.org/10.1016/S0022-4359(99)00025-1.

Han, S., Gupta, S., \& Lehmann, D. (2001). Consumer price sensitivity and price thresholds. Journal of Retailing, 77(4), 435-456, doi:10.1016/S0022-4359(01)00057-4, http://dx.doi.org/10.1016/S0022-4359(01)00057-4.

Hausman, A. (2000). A multi-method investigation of consumer motivations in impulse buying behavior. Journal of Consumer Marketing, 17(4/5), 403-419.

Heidarzaeh Hanzaee, K., \& Aghasibeig, S. (2008). Generation Y female and male decision-making styles in Iran: are they different. The International Review of Retail, Distribution and Consumer Research, 18(5), 521-537, doi:10.1080/09593960802573443, http://dx.doi.org/10.1080/09593960802573443.

Hirschman, E. C. (1983). Predictors of self-projection, fantasy fulfillment, and escapism. Journal of Social Psychology, 120(1), 63-76, doi:10.1080/00224545.1983.9712011, http://dx.doi.org/10.1080/00224545.1983.9712011.

Hirschman, E. C. (1984). Experience seeking: a subjectivist perspective of consumption. Journal of Business Research, 12(1), 115-136, doi:10.1016/0148-2963(84)90042-0, http://dx.doi.org/10.1016/0148-2963(84)90042-0.

Hirschman, E. C. (1992). The consciousness of addiction: toward a general theory of compulsive consumption. Journal of Consumer Research, 19(2), 155-179, doi:10.1086/209294, http://dx.doi.org/10.1086/209294.

Hirschman, E. C., \& Holbrook, M. (1982). Hedonic consumption: emerging concepts, methods and propositions. Journal of Marketing, 46(3), 92-101, doi:10.2307/1251707, http://dx.doi.org/10.2307/1251707.

Holbrook, M. (1996). Customer value: a framework for analysis and research. Advances in Consumer Research, 23(1), 138-142.

Holbrook, M., \& Hirschman, E. C. (1982). The experiential aspects of consumption: consumer fantasies, feelings, and fun. Journal of Consumer Research, 9(2), 132-140, doi:10.1086/208906, http://dx.doi.org/10.1086/208906. 
Holbrook, M., Chestnut, R., Oliva, T., \& Greenleaf, E. (1984). Play as a consumption experience: the roles of emotions, performance, and personality in the enjoyment of games. Journal of Consumer Research, 11(2), 728-739, doi:10.1086/209009, http://dx.doi.org/10.1086/209009.

Jin, B., \& Kim, J. O. (2003). A typology of Korean discount shoppers: shopping motives, store attributes, and outcomes. International Journal of Service Industry Management, 14(4), 396-419.

Jones, M., \& Reynolds, K. E. (2006). The role of retailer interest on shopping behavior, Journal of Retailing, 82(2), 115-126, doi:10.1016/j.jretai.2005.05.001, http://dx.doi.org/10.1016/j.jretai.2005.05.001.

Jones, M. A., Reynolds, K. E., \& Arnold, M. (2006). Hedonic and utilitarian shopping value: investigating differential effects on retail outcomes. Journal of Business Research, 59(9), 974-981, doi:10.1016/j.jbusres.2006.03.006, http://dx.doi.org/10.1016/j.jbusres.2006.03.006.

Kahn, B., \& Isen, A. (1993). The influence of positive affect on variety-seeking among safe, enjoyable products. Journal of Consumer Research, 20(2), 257-270, doi:10.1086/209347, http://dx.doi.org/10.1086/209347.

Kahn, B. E. (1995). Consumer variety-seeking among goods and services. Journal of Retailing and Consumer Services, 2(3), 139-148, doi:10.1016/0969-6989(95)00038-0, http://dx.doi.org/10.1016/0969-6989(95)00038-0.

Kanetkar, V., Weinberg, C., \& Weiss, D. (1992). Price sensitivity and television advertising exposures: Some empirical findings. Marketing Science, 11(4), 359-71, doi:10.1287/mksc.11.4.359, http://dx.doi.org/10.1287/mksc.11.4.359.

Kempf, D. (1999). Attitude formation from product trial: distinct roles of cognition and affect for hedonic and functional products. Psychology \& Marketing, $16(1), \quad 35-50$, doi:10.1002/(SICI)1520-6793(199901)16:1<35::AID-MAR3>3.3.CO;2-L, http://dx.doi.org/10.1002/(SICI)1520-6793(199901)16:1<35::AID-MAR3>3.3.CO;2-L.

Kim, H. (2005). Consumer profiles of apparel product involvement and values. Journal of Fashion Marketing and Management, 9(2), 207-20.

Krejcie, R. V., \& Morgan, D. W. (1970). Determining sample size for research activities. Educational and Psychological Measurement, 30, 607-610.

Laurent, G., \& Kapferer, J. (1985). Measuring consumer involvement profiles. Journal of Marketing Research (JMR), 22(1), 41-53, doi:10.2307/3151549, http://dx.doi.org/10.2307/3151549.

Lee, M., Kim, Y., \& Fairhurst, A. (2009). Shopping value in online auctions: their antecedents and outcomes. Journal of Retailing \& Consumer Services, 16(1), 75-82, doi:10.1016/j.jretconser.2008.11.003, http://dx.doi.org/10.1016/j.jretconser.2008.11.003.

Lehtonen, T. (1994). Shopping as a form of social. Sosiologia, 3, 192-203.

Library of Congress, Federal Research Division, (2008), Country Profile: Iran. Library of Congress. [Online] Available: http://lcweb2.loc.gov/frd/cs/profiles/Iran.pdf (September 12, 2010).

MacInnis, D., \& Price, L. (1987). The role of imagery in information processing: review and extensions. Journal of Consumer Research, 13(4), 473-491, doi:10.1086/209082, http://dx.doi.org/10.1086/209082.

Markin, R., Lillis, C., \& Narayana, C. (1976). Social-psychological significance of store space. Journal of Retailing, 52(1), 43-54.

Martin, C. (1998). Relationship marketing: a high-involvement product attribute approach. Journal of Product \& Brand Management, 7(1), 6-26.

Maxham III, J., \& Netemeyer, R. (2002). A longitudinal study of complaining custorners' evaluations of multiple service failures and recovery efforts. Journal of Marketing, 66(4), 57-71, doi:10.1509/jmkg.66.4.57.18512, http://dx.doi.org/10.1509/jmkg.66.4.57.18512.

McAlister, L., \& Pessemier, E. (1982). Variety-seeking behavior: an interdisciplinary review. Journal of Consumer Research, 9(3), 311-322, doi:10.1086/208926, http://dx.doi.org/10.1086/208926.

Menon, S., \& Kahn, B. (1995). The impact of context on variety-seeking in product choices. Journal of Consumer Research, 22(3), 285-295, doi:10.1086/209450, http://dx.doi.org/10.1086/209450.

Michaelidou, N., Arnott, D., \& Dibb, S. (2005). Characteristics of marketing channels: a theoretical framework. Marketing Review, 5(1), 45-57, doi:10.1362/1469347053294788, http://dx.doi.org/10.1362/1469347053294788. 
O'Guinn, T., \& Faber, R. (1989). Compulsive buying: a phenomenological exploration. Journal of Consumer Research, 16(2), 147-157, doi:10.1086/209204, http://dx.doi.org/10.1086/209204.

Oliver, R. L. (1980). A cognitive model of the antecedents and consequences of satisfaction decisions. Journal of Marketing Research (JMR), 17(4), 460-469, doi:10.2307/3150499, http://dx.doi.org/10.2307/3150499.

Oliver, R. L. (1993). Cognitive, affective, and attribute bases of the satisfaction response. Journal of Consumer Research, 20(3), 418-430, doi:10.1086/209358, http://dx.doi.org/10.1086/209358.

Overby, J., \& Lee, E. (2006). The effects of utilitarian and hedonic online shopping value on consumer preference and intentions. Journal of Business Research, 59(10/11), 1160-1166, doi:10.1016/j.jbusres.2006.03.008, http://dx.doi.org/10.1016/j.jbusres.2006.03.008.

Park, E. J., Kim, E. Y., \& Forney, J. C. (2006). A structural model of fashion-oriented impulse buying behavior. Journal of Fashion Marketing \& Management, 10(4), 433-446.

Research \& Markets, (2007), Automotive Industry and Market of Iran 2007, Research and Markets. [Online] Available: http://www.researchandmarkets.com/reportinfo.asp?report_id=473730 (accessed 12 September 2010).

Roehm, H., \& Roehm, M. (2005). Revisiting the effect of positive Mood on variety-seeking. Journal of Consumer Research, 32(2), 330-336.

Rogers, R. D. (1979). Commentary on the neglected variety drive. Journal of Consumer Research, 6(1), 88-91, doi:10.1086/208752, http://dx.doi.org/10.1086/208752.

Rook, D. W. (1987). The buying impulse. Journal of Consumer Research, 14(2), 189-199, doi:10.1086/209105, http://dx.doi.org/10.1086/209105.

Rook, D. W., \& Fisher, R. J. (1995). Normative influences on impulsive buying behavior. Journal of Consumer Research, 22(3), 305-313, doi:10.1086/209452, http://dx.doi.org/10.1086/209452.

Scarpi, D. (2005). Hedonic and utilitarian behaviour in specialty shops. Marketing Review, 5(1), 31-44, doi:10.1362/1469347053294797, http://dx.doi.org/10.1362/1469347053294797.

Schindler, R. M. (1989). The excitement of getting a bargain: some Hypotheses concerning the origins and effects of smart-shopper feelings. Advances in Consumer Research, 16(1), 447-453.

Seo, S., \& Lee, Y. (2008). Shopping values of clothing retailers perceived by consumers of different social classes. Journal of Retailing \& Consumer Services, 15 (6), 491-499, doi:10.1016/j.jretconser.2008.02.001, http://dx.doi.org/10.1016/j.jretconser.2008.02.001.

Sharma, P., Sivakumaran, B., \& Marshall, R. (2006). Investigating impulse buying and variety-seeking: towards a general theory of hedonic purchase behaviors. Advances in Consumer Research, 33(1), 388-389.

Sherry, J. F. (1990). A sociocultural analysis of a Midwestern American flea market. Journal of Consumer Research, 17(1), 13-30.

Smith, M. F., \& Carsky, M. L. (1996). Grocery shopping behavior: a comparison of involved and uninvolved consumers. Journal of Retailing and Consumer Services, 3(2), 73-80, doi:10.1016/0969-6989(95)00048-8, http://dx.doi.org/10.1016/0969-6989(95)00048-8.

Soltani, E. (2002). Iran: a land of apparel opportunity? [Online] Available: http://www.just-style.com/article.aspx?id=92975 (September 12, 2010).

Steenkamp, J. E. M., \& Baumgartner, H. (1995). Development and cross-cultural validation of a short form of CSI as a measure of optimum stimulation level. International Journal of Research in Marketing, 12 (2), 97-104, doi:10.1016/0167-8116(93)E0035-8, http://dx.doi.org/10.1016/0167-8116(93)E0035-8.

Tauber, E. M. (1972). Why do people shop? Journal of Marketing, 36(4), 46-49, doi:10.2307/1250426, http://dx.doi.org/10.2307/1250426.

UNICEF. (2008). At a glance: Iran, Islamic Republic of. UNICEF. [Online] Available: http://www.unicef.org/infobycountry/iran_2142.html (September 12, 2010).

Van Tripj, H., Hoyer, W., \& Inman, J. (1996). Why switch? Product category-level explanations for true variety-seeking behavior. Journal of Marketing Research (JMR), 33(3), 281-292.

Westbrook, R. A., \& Black, W. (1985). A motivation-based shopper typology. Journal of Retailing, 61(1), 78-103. 
Zaichkowsky, J. L. (1985). Measuring the involvement construct. Journal of Consumer Research, 12(3), 341-352, doi:10.1086/208520, http://dx.doi.org/10.1086/208520.

Zeithaml, V. A. (1988). Consumer perceptions of price, quality, and value: a means-end model and synthesis of evidence. Journal of Marketing, 52(3), 2-22, doi:10.2307/1251446, http://dx.doi.org/10.2307/1251446.

Table 1. Contrast between Hedonic and Utilitarian Shopping Value (Lehtonen, 1994, 193)

\begin{tabular}{|llll|}
\hline \multicolumn{1}{|c}{ Hedonic shopping value } & Utilitarian shopping value \\
\hline - & An end itself & $\bullet$ & A means to an end \\
\hline - & Does not necessarily include purchases & $\bullet$ & Always includes purchases \\
\hline - & Impulsive & $\bullet$ & Planned \\
\hline - & Efficiency not central & $\bullet$ & As efficient as possible \\
\hline - & For pleasure & $\bullet$ & Out of necessity \\
\hline - & Outside of daily routines & $\bullet$ & Part of daily routine \\
\hline - & No clear beginning or end & $\bullet$ & Clear beginning and end \\
\hline$\bullet$ & Emphasis of the experience & $\bullet$ & Emphasis of rationality \\
\hline
\end{tabular}


Table 2. Variables and Their Measures (Confirmatory Factor Analysis)

\begin{tabular}{|c|c|c|c|}
\hline constructs & Items & Estimates & t- value \\
\hline \multirow{11}{*}{$\begin{array}{l}\text { Variety-seeking } \\
\text { tendency } \\
(\alpha=0.94)\end{array}$} & $\begin{array}{l}\text { I like to continue doing the same old things rather than trying } \\
\text { new and different things. (-) }\end{array}$ & 1.00 & ---- \\
\hline & I like to experience novelty and change in my daily routine. & 1.33 & $30.61 * * *$ \\
\hline & I like a job that offers change, variety, and travel, even if it & 1.23 & $27.94 * * *$ \\
\hline & I am continually seeking new ideas and experiences. & 1.29 & $29.32 * * *$ \\
\hline & I like continually changing activities. & 1.21 & $28.54 * * *$ \\
\hline & $\begin{array}{l}\text { When things get boring, I like to find some new and unfamiliar } \\
\text { experience. }\end{array}$ & 1.22 & $28.94 * * *$ \\
\hline & $\begin{array}{l}\text { I prefer a routine way of life to an unpredictable one full of } \\
\text { change.(-) }\end{array}$ & 1.14 & $26.79 * * *$ \\
\hline & $\begin{array}{l}\text { I am very cautious in trying new or different styles of Manto } \\
\text { or Shirt. (-) }\end{array}$ & 1.05 & $25.38 * * *$ \\
\hline & $\begin{array}{l}\text { I enjoy taking changes in buying new styles of Manto or Shirt } \\
\text { just to get some variety in my purchases. }\end{array}$ & 1.07 & $25.95 * * *$ \\
\hline & $\begin{array}{l}\text { I rarely buy new Manto or Shirt styles about which I am } \\
\text { uncertain. (-) }\end{array}$ & 1.10 & \\
\hline & $\begin{array}{l}\text { When old Manto or Shirt gets boring, I like to find some new } \\
\text { styles and products. }\end{array}$ & 1.15 & $26.80 * * *$ \\
\hline \multirow[t]{6}{*}{$\begin{array}{l}\text { Price sensitivity } \\
(\alpha=0.94)\end{array}$} & $\begin{array}{l}\text { I don't mind spending a lot of money to buy a new Manto or } \\
\text { Shirt. }\end{array}$ & 1.00 & \\
\hline & I don't mind paying more to try out a new Manto or Shirt. & 0.97 & $59.44 * * *$ \\
\hline & I am less willing to buy a new Manto or Shirt if I think that it & 0.83 & $45.51 * * *$ \\
\hline & $\begin{array}{l}\text { I know that a new Manto or Shirt is likely to be more } \\
\text { expensive than high in price. }\end{array}$ & 0.97 & $51.74 * * *$ \\
\hline & $\begin{array}{l}\text { A really great new Manto or Shirt is worth paying a lot of } \\
\text { money for. }\end{array}$ & 0.88 & $45.61 * * *$ \\
\hline & $\begin{array}{l}\text { In general, the price or cost of buying a new Manto or Shirt is } \\
\text { important to me. }\end{array}$ & 0.77 & $39.95^{* * *}$ \\
\hline \multirow{4}{*}{$\begin{array}{l}\text { Utilitarian } \\
(\alpha=0.84)\end{array}$} & I accomplished just what I wanted to on this shopping trip. & 1.00 & --- \\
\hline & I couldn't buy what I really needed. & 0.95 & $29.54 * * *$ \\
\hline & While shopping, I found just the item(s) I was looking for. & 0.87 & $28.99 * * *$ \\
\hline & $\begin{array}{l}\text { I was disappointed because I had to go to another store(s) to } \\
\text { complete my shopping. }\end{array}$ & 1.01 & $28.40 * * *$ \\
\hline \multirow[t]{9}{*}{$\begin{array}{l}\text { Hedonic value } \\
(\alpha=0.90)\end{array}$} & $\begin{array}{l}\text { This shopping trip was truly a joy. } \\
\text { I continued to shop, not because I had to, but because I wanted } \\
\text { to. }\end{array}$ & $\begin{array}{l}1.00 \\
0.81\end{array}$ & $30.86^{* * *}$ \\
\hline & $\begin{array}{l}\text { Compared to other things I could have done, the time spent } \\
\text { shopping was truly enjoyable. }\end{array}$ & 0.82 & $34.32 * * *$ \\
\hline & I enjoyed being immersed in exciting new products. & 0.88 & $33.78^{* * *}$ \\
\hline & $\begin{array}{l}\text { I enjoyed this shopping trip for its own sake, not just for the } \\
\text { items I may have purchased. }\end{array}$ & 0.81 & $33.03 * * *$ \\
\hline & $\begin{array}{l}\text { I had a good time because I was able to act on the } \\
\text { spur-of-the-moment. }\end{array}$ & 0.52 & $20.23 * * *$ \\
\hline & During the trip, I felt the excitement of the hunt. & 0.84 & $32.54 * * *$ \\
\hline & While shopping, I was able to forget my problems. & 0.66 & $27.10 * * *$ \\
\hline & While shopping, I felt a sense of adventure. & 0.70 & $28.77 * * *$ \\
\hline & This shopping trip was not a very nice time out. (-) & 0.62 & $22.30 * * *$ \\
\hline \multirow{6}{*}{$\begin{array}{l}\text { Shopping } \\
\text { satisfaction } \\
(\alpha=0.86)\end{array}$} & I am happy with the outcome of that shopping trip. & 1.00 & --- \\
\hline & I am satisfied with this store. & 0.76 & $25.19 * * *$ \\
\hline & Overall, I am not satisfied with this store. (-) & 0.72 & $22.58 * * *$ \\
\hline & I am please with the outcome of that shopping trip. & 0.84 & $29.58 * * *$ \\
\hline & I am contented with the outcome of that shopping trip. & 0.85 & $30.07 * * *$ \\
\hline & Overall, I am satisfied with the outcome of that shopping trip. & 0.75 & $25.38 * * *$ \\
\hline
\end{tabular}


Table 3. Standardized Coefficients and Fit Statistics for the Structural Model

\begin{tabular}{|l|l|c|c|}
\hline Hypothesis & \multicolumn{1}{|c|}{ Structural paths } & Estimates & t-Value \\
\hline H1 & $\begin{array}{l}\text { Variety-seeking buying tendency } \rightarrow \\
\text { Utilitarian Value }\end{array}$ & 0.23 & $5.34^{* *}$ \\
\hline H2 & $\begin{array}{l}\text { Variety-seeking buying tendency } \rightarrow \\
\text { Hedonic Value }\end{array}$ & 0.41 & $8.96^{* *}$ \\
\hline H3 & Price sensitivity $\rightarrow$ Utilitarian Value & 0.01 & 0.42 \\
\hline H4 & Price sensitivity $\rightarrow$ Hedonic Value & -0.11 & $15.43^{* *}$ \\
\hline H5 & Utilitarian Value $\rightarrow$ Shopping satisfaction & 0.41 & $11.00^{* *}$ \\
\hline H6 & Hedonic Value $\rightarrow$ Shopping satisfaction & 0.24 & \\
\hline Fit statistics & \multicolumn{2}{|c|}{0.066} \\
\hline$\chi^{2}(d f)=\chi^{2} / p-V a l u e$ & $\chi^{2}(622)=4595 / 0.000$ \\
\hline Root mean-square error of approximation (RMSEA) & & 0.95 \\
\hline Comparative fit index (CFI) & & \\
\hline
\end{tabular}

$$
* \mathrm{p}<0.05, * * \mathrm{p}<0.01
$$

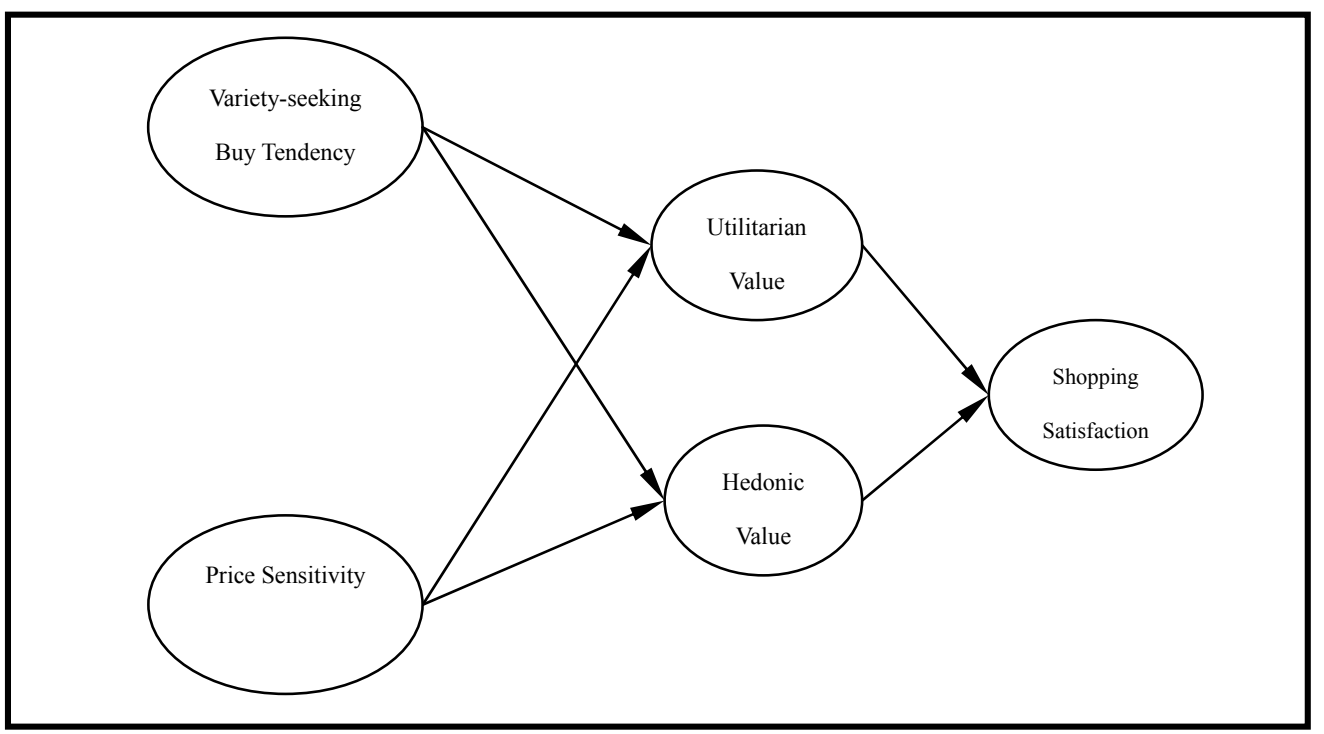

Figure 1: Conceptual Model

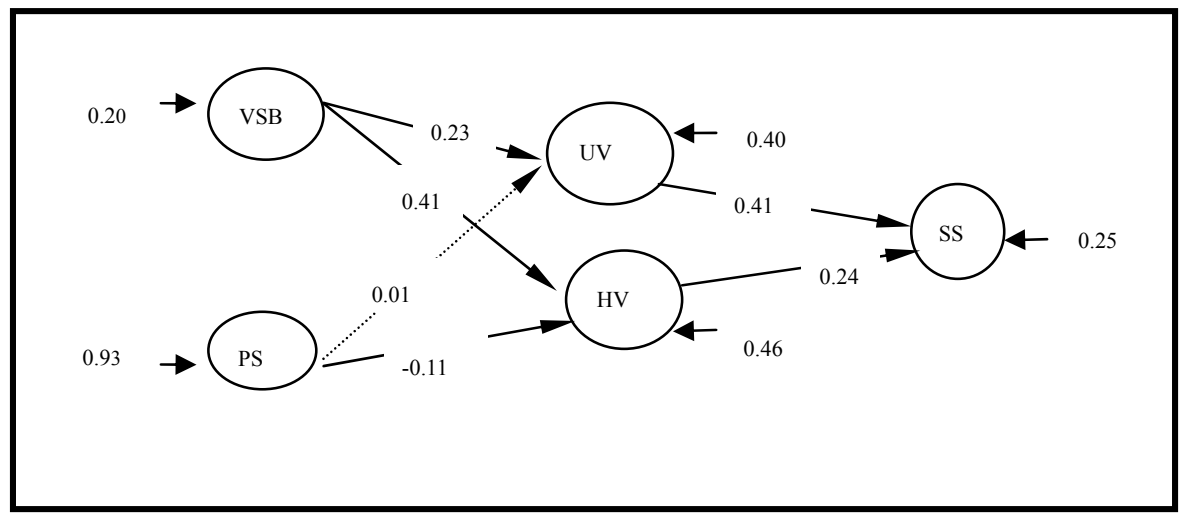

Figure 2: The Results of SEM 